\title{
Sphingosine 1-Phosphate Receptor 3
}

National Cancer Institute

\section{Source}

National Cancer Institute. Sphingosine 1-Phosphate Receptor 3. NCI Thesaurus. Code C104778.

Sphing osine 1-phosphate receptor 3 (378 aa, $\sim 42 \mathrm{kDa}$ ) is encoded by the human S1PR3 gene. This $\mathrm{G}$ protein-coupled receptor may play a role in vascular endothelial cell function and regulation of angiogenesis. 